\title{
Special issue on the 13th Brazilian meeting on adsorption
}

\author{
Célio L. Cavalcante Jr. ${ }^{1}$ Moisés Bastos-Neto ${ }^{1}$ Alírio E. Rodrigues ${ }^{2} \cdot$ Arvind Rajendran $^{3}$
}

Received: 28 September 2021 / Revised: 28 September 2021 / Accepted: 28 September 2021 / Published online: 8 October 2021

(c) The Author(s), under exclusive licence to Springer Science+Business Media, LLC, part of Springer Nature 2021

This Special Issue of ADSORPTION presents selected papers from the 13th Brazilian Meeting on Adsorption, held in December 2020 in an all digital format, due to the Covid-19 pandemic. The conference was chaired by Prof. Diana Azevedo (UFC, Fortaleza, Brazil) and broadcasted live by a digital platform from Nov 30th to Dec 3rd 2020. The Brazilian Meeting on Adsorption (acronym EBA, in Portuguese) has been held every 2 years since 1996 by different institutions across Brazil, alternating venues in the Northeast and South/Southeast regions. The main objective of the conference is to bring together the scientific, academic and industrial communities related to the Adsorption field in Brazil and abroad. The event disseminates the science of Adsorption in the academic and industrial environment, showcasing the latest progress in the area, fostering interaction and networking among researchers and entrepreneurs in this field.

For this 13th edition of the meeting, participants connected from different places around the world (15 other countries) and in Brazil (from 18 states). Prior to the scientific event itself, an "Adsorption School" was organized with six tutorials given by experts in the field, covering all aspects of the fundamentals of adsorption (from experiments to modeling) with nearly 80 active students. During the meeting, 4 keynotes, 6 plenary lectures and 20 invited talks were presented by outstanding researchers from Brazil and from abroad. The keynote lectures covered themes of $\mathrm{CO}_{2}$

Célio L. Cavalcante Jr.

celio@gpsa.ufc.br

Moisés Bastos-Neto

moises@gpsa.ufc.br

Alírio E. Rodrigues

arodrig@fe.up.pt

Arvind Rajendran

arajendr@ualberta.ca

1 Universidade Federal do Ceará, Fortaleza, Brazil

2 Universidade do Porto, Porto, Portugal

3 University of Alberta, Edmonton, Canada capture by adsorption (Paul Webley, Australia), nanopores characterization (Conchi Annia, France), molecular simulation (S. Mardonio Lucena, Brazil) and biogas processing by adsorption (Carlos Grande, Norway). The technical sessions comprised of 51 oral presentations and 131 poster presentations, with intense discussions and collaborations through the live digital platform made available by the event organizers. Despite the innovative format of this digital event, EBA 13 drew the registration of nearly 250 attendees among academics, scientists, (graduate and undergraduate) students and industrial practitioners from Chemistry, Chemical Engineering, Materials Engineering, Food Engineering, Environmental Engineering, Physics and related fields. The full Proceedings of EBA-13 are available as an e-book available at the UFC website (http://www.editora.ufc.br/68-livros-digit ais/990-anais-do-13-encontro-brasileiro-de-adsorcao-eba), highlighting this historical landmark of a fully digital scientific meeting, 24 years after the 1 st in-person edition, that had also been organized by the UFC Adsorption Research group in 1996. The organizers of this 13th Brazilian Meeting on Adsorption take this opportunity to acknowledge funding obtained from the Brazilian government through the funding agencies CAPES and CNPq. The financial support from the companies Pensalab, Ametek, Hiden Isochema, 3P Instruments and Acil Weber, is also gratefully acknowledged. Finally, the conference was only made possible under the auspices of Fundação ASTEF, IKONE Eventos and UFCUniversidade Federal do Ceará.

The Scientific Committee, chaired by Prof. Moises Bastos-Neto, pre-selected 19 presented papers to be submitted to this Special Issue on ADSORPTION in a full article version in the Springer online submission system. After rigorous evaluations by international reviewers, 12 have been selected by the guest editors for publication in this Special Issue. Other manuscripts that did not reach a final decision in time for this S.I. may still be published, if accepted, in subsequent regular issues of the journal, with a footnote relating them to the 13th Brazilian Meeting on Adsorption. The selected papers cover several aspects of adsorption (equilibrium, kinetics, characterizations, simulations, PSA, adsorbent 
synthesis and applications). The guest editors are grateful to all authors and reviewers that contributed to this issue in a timely way.

Addendum All members of the Brazilian Adsorption community want to express their deepest feelings for the recent death of Prof. Douglas M. Ruthven (University of New Brunswick, Canada/University of Maine, USA) this Sept 23, 2021. Prof. Ruthven presented several Plenary Lectures and Short Courses on Adsorption Fundamentals and Processes along many editions of our Brazilian Meetings on Adsorption (EBA's), including the very first one, in Fortaleza, 1996. Of this, he kept a memento in his office until his retirement, a printed sign indicating "Sala Caju" (Room "Caju", in Portuguese), which he took off the wall of the event venue after that very first memorable EBA. Doug, we feel "muita saudade" of your lessons, your hard work, your companionship and, above all, your friendship to us all.

Publisher's Note Springer Nature remains neutral with regard to jurisdictional claims in published maps and institutional affiliations. 